\title{
Characterization and Expression Analysis of a Retinoblastoma-Related Gene from Chinese Wild Vitis pseudoreticulata
}

\author{
Zhifeng Wen • Min Gao $\cdot$ Chen Jiao • Qian Wang • \\ Hui Xu • Monika Walter • Weirong Xu • Carole Bassett • \\ Xiping Wang
}

Published online: 19 January 2012

(C) The Author(s) 2012. This article is published with open access at Springerlink.com

\begin{abstract}
Retinoblastoma-related (RBR) genes, a conserved gene family in higher eukaryotes, play important roles in cell differentiation, development, and mammalian cell death; however, little is known of their function in plants. In this study, a RBR gene was isolated from the Chinese wild grape, Vitis pseudoreticulata W. T. Wang clone "Baihe-35-1", and designated as VPRBR. The cDNA sequence of $V p R B R$ was 3,030 bp and contained an open reading frame of 3,024 bp. Conceptual translation of this gene indicated a composition of 1,007 amino acids with a predicted molecular mass of $117.3 \mathrm{kDa}$. The predicted protein showed a retinoblastoma-associated protein domain $\mathrm{A}$ from amino acid residues 416 to 579 , and domain B from
\end{abstract}

Z. Wen $\cdot$ M. Gao $\cdot$ C. Jiao $\cdot$ Q. Wang $\cdot$ H. Xu $\cdot$ M. Walter $\cdot$

X. Wang

Key Laboratory of Horticultural Plant Biology and Germplasm Innovation in Northwest China, Ministry of Agriculture, College of Horticulture, Northwest A \& F University,

Yangling, Shaanxi 712100, People's Republic of China

Z. Wen $\cdot$ M. Gao $\cdot$ C. Jiao $\cdot$ Q. Wang $\cdot$ H. Xu $\cdot$ X. Wang $(\bowtie)$

State Key Laboratory of Crop Stress Biology in Arid Areas

(Northwest A\&F University),

Yangling, Shaanxi 712100, People's Republic of China

e-mail: wangxiping@nwsuaf.edu.cn

X. Wang

e-mail: wangxiping89@gmail.com

W. Xu

School of Agriculture, Ningxia University,

Yinchuan, Ningxia 750021, People's Republic of China

C. Bassett

USDA-ARS, Appalachian Fruit Research Station,

2217 Wiltshire Road,

Kearneysville, WV 25430, USA residues 726 to 855 . The result of expression analysis indicated that $V p R B R$ was expressed in tissues, leaves, stem, tendrils, flower, and grape skin at different expression levels. Further quantitative reverse transcription-PCR (qRT-PCR) data indicated that $V p R B R$ levels were higher in Erysiphe necator-treated "Baihe-35-1" and "Baihe-131", two resistant clones of Chinese wild $V$. pseudoreticulata, than in E. necator-treated "Hunan-1", a susceptible clone of $V$. pseudoreticulata. Furthermore, the expression of $V p R B R$ in response to salicylic acid (SA), methyl jasmonate (MeJA), and ethylene (Eth) in grape leaves was also investigated. Taken together, these data indicate that $V P R B R$ may contribute to some aspect of powdery mildew resistance in grape.

Keywords Vitis pseudoreticulata $\cdot$ Retinoblastoma-related gene $\cdot$ Powdery mildew $\cdot$ Expression analysis

\begin{tabular}{ll}
\multicolumn{2}{l}{ Abbreviations } \\
bp & Base pair \\
$\mathrm{ddH}_{2} \mathrm{O}$ & Double distilled water \\
$\mathrm{Eth}$ & Ethylene \\
hpi & Hours post inoculation \\
$\mathrm{MeJA}$ & Methyl jasmonate \\
$\mathrm{ORF}$ & Open reading frame \\
$\mathrm{PM}$ & Powdery mildew \\
qRT-PCR & Quantitative reverse transcription polymerase \\
& chain reaction \\
pRBR & Retinoblastoma-related proteins \\
$\mathrm{SA}$ & Salicylic acid \\
SDS & Sodium dodecylsulfate \\
SCAR & Sequence characterized amplified regions \\
VpRBR & Vitis pseudoreticulata retinoblastoma-related \\
& gene
\end{tabular}




\section{Introduction}

Grapevine is one of the economically most important cultivated plants worldwide. Grapevines are threatened by various biotic (viruses, bacteria, fungi, and insects) and abiotic stresses (drought, winter cold) (Akkurt et al. 2008). Powdery mildew (PM) caused by Erysiphe necator (Schw.) Burr. is a significant fungal disease of grapevine worldwide, causing yield loss and reduction in berry quality (Fung et al. 2008). The most widely grown grapevine cultivars are European grapes derived from Vitis vinifera which are highly susceptible to E. necator. Developing grape cultivars with high levels of durable resistance is a key long-term strategy for controlling and managing PM.

A number of wild grapevine species carry different valuable genes resistant to PM (Wang et al. 1995), thus providing a potential source of resistance for grapevine breeding. Of these wild Vitis species, the Chinese wild Vitis pseudoreticulata W. T Wang clone "Baihe-35-1" was shown to possess potentially durable, race non-specific PM resistance (Wang et al. 1995). Identifying the genes that confer resistance in Chinese wild Vitis species and understanding the genetic molecular basis of the resistance to PM are crucial for generating new, superior grapevine varieties. Molecular resistance mechanisms of PM have been described in grapevine. Fekete et al. (2009), for example, identified 25 grapevine transcripts which increased in abundance upon infection of leaves in the PM-susceptible host, $V$. vinifera Cabernet Sauvignon. Riaz et al. (2011) constructed a genetic map utilizing five grape populations segregating for powdery mildew resistance. Their data indicated that PM resistance genes from different backgrounds reside on chromosome 18. Akkurt et al. (2008) obtained two amplification products by SCAR analysis from predominantly resistant individuals, and the presence of these products correlated with disease resistance. Ramming et al. (2011) suggested a single dominant locus, ren4, conferred rapid non-race-specific resistance to grapevine PM, and Ali et al. (2009) proposed that resistance might be associated with metabolites in grapevines. All these studies indicate that genetic resistance naturally exists in grapevine and underscore the inherent complexity of that resistance in grapevine.

In order to resist pathogen infection, plants have developed sophisticated mechanisms in which some disease-resistant genes play important roles and appear to be effective against pathogen attack (Ma et al. 2010; Peng et al. 2011). A recent study on the stimulation of plant signaling pathways suggested that a thorough understanding of grapevine innate defense mechanisms was a prerequisite to the development of new protection strategies (Henanff et al. 2011). Although some molecular aspects of the host-pathogen interaction have already been studied in grapevine (Ali et al. 2009; Akkurt et al. 2008; Fekete et al. 2009), the resistance mechanism(s) is not yet understood at the molecular level for any of these interactions. Therefore, the use of molecular analytical approaches to improve knowledge about the interaction between wild grapevine species and E. necator is of great importance.

The retinoblastoma protein $(\mathrm{RB})$ is a tumor-suppressor protein that is dysfunctional in many types of cancer (Murphree and Benedict 1984). They have been shown to function as important regulators of several cellular processes, including differentiation, control of gene expression, and apoptosis (Miskolczi et al. 2007). In plants, a retinoblastomarelated (RBR) gene was first identified and cloned from maize (Grafi et al. 1996); it was later identified from other plants, including tobacco (Nakagami et al. 1999), rice (Lendvai et al. 1997), and Arabidopsis thaliana (Kong et al. 2000). Although RBR genes have been isolated from diverse plant species, their functions in plant disease resistance have not yet been elucidated.

In our previous study using differential display reverse transcript-polymerase chain reaction, we observed an mRNA that was induced in leaves of $V$. pseudoreticulata W. T. Wang clone "Baihe-35-1" upon infection with $E$. necator (Wang et al. 2011). We analyzed the sequence of the cDNA fragment and found that it contains the domain $\mathrm{B}$ motif conserved in all $R B R$ genes. Since "Baihe-35-1" has been shown to be highly resistant to powdery mildew, we undertook the present study to gain a better understanding of $V p R B R$ in grapevine and its potential role in PM resistance. We cloned the full-length RBR gene from "Baihe-35-1" using a rapid amplification of cDNA ends (RACE) strategy and further analyzed its expression pattern in response to $E$. necator, salicylic acid (SA), methyl jasmonate (MeJA), and ethylene (Eth). The aim of this study was to determine whether or not there was a relationship between grapevine resistance and the response of $V P R B R$ to E. necator infection. To our knowledge, this is the first report of an RBR gene potentially related to PM resistance in plants.

\section{Materials and Methods}

\section{Plant Material}

PM-highly resistant Chinese wild V. pseudoreticulata clones "Baihe-35-1" and "Baihe-13-1", and a PM-susceptible Chinese wild V.pseudoreticulata clone "Hunan-1" (Wang et al. 1995) were maintained in the grape germplasm resources orchard, Northwest A\&F University, Yangling Shaanxi, 712100 , P. R. China. When shoots of the vines were 30 $40 \mathrm{~cm}$ in length, the third to sixth fully expanded young grapevine leaves below the apex were selected for treatments. E. necator (also known as Uncinula necator Burr.) 
was collected from the leaves of a highly PM-susceptible Chinese wild $V$. adstricta Hance clone "Taishan-2" in the grape germplasm resource orchard, Northwest A\&F University, Yangling Shaanxi, 712100, P. R. China.

E. necator Inoculation and SA, Eth, and MeJA Treatments

Inoculation of E. necator on grapevine leaves was conducted according to the protocol previously described by Wang et al. (1995) and was repeated three times on three independent plants for each clone. Leaves sprayed with sterile water were used as negative controls. At each inoculation period, leaves were sampled after $0,4,8,12,24,48,72$ and $120 \mathrm{~h}$ of inoculation, immediately frozen in liquid nitrogen, and stored at $-80^{\circ} \mathrm{C}$ for further study.

For signaling molecule treatments, $100 \mu \mathrm{M} \mathrm{SA}, 50 \mu \mathrm{M}$ Eth, and $0.5 \mathrm{~g} / \mathrm{L}$ MeJA were sprayed on the selected grapevine leaves according to the method described ( $\mathrm{Li}$ et al. 2010), and was repeated three times on three independent plants for each species. Leaves sprayed with sterile water were used as negative controls. After 0, 0.5, 1, 3, 6, 12, 24 and $48 \mathrm{~h}$ of inoculation, the treated grapevine leaves were sampled, immediately frozen in liquid nitrogen, and stored at $-80^{\circ} \mathrm{C}$ for further study.

\section{RNA Extraction and Purification}

Total RNA was isolated from grapevine leaves using an improved SDS/phenol method (Zhang et al. 2003). Residual DNA was removed by DNase I (Promega, Madison, WI, USA). Concentration of total RNA was measured with an ultraviolet spectrophotometer (V-550, JASCO, Japan) at $260 \mathrm{~nm}$. RNA purity was checked by determining the $\mathrm{A}_{260} / \mathrm{A}_{280}$ ratio, and RNA integrity was examined by $1 \%$ agarose gel electrophoresis.

\section{5'RACE and 3'RACE Clone the Full-length $V p R B R$ cDNA}

In order to obtain the full-length cDNA of $V p R B R$, a rapid amplification of $5^{\prime}$ end cDNA (5'RACE) and $3^{\prime}$ end (3'RACE) PCR amplifications were carried out on genomic DNA isolated from V.pseudoreticulata. The gene-specific primers, GSP 1 (5'-ACG TAT AAT TAC GAA GGA CAC CAC C-3') for 5'RACE and GSP 2 (5'-TCC AGG ACG CGA AGG GGA AAC ATG T-3') for $3^{\prime}$ RACE, were designed based on the partial $V p R B R$ sequence obtained previously (Wang et al. 2011). The length between the two specific primers was 243 bp. Total RNA of "Baihe-35-1" leaves inoculated with E. necator after $120 \mathrm{~h}$ was isolated as described above, and RACE was performed using a BD SMART ${ }^{\mathrm{TM}}$ RACE cDNA Amplification Kit (Clontech, Palo Alto, CA, USA) according to the manufacturer's instructions. The 5' and $3^{\prime}$ RACE products were separated on $1.2 \%$ agarose gels and purified by an agarose gel DNA fragment recovery kit (Hufeng, Shanghai, China). The fragments were cloned into the pGEM-T easy vector (Promega), and sequenced by Sango Biotech (Shanghai, China).

\section{Sequence Analysis}

Similarity analysis of nucleotide and protein sequences was carried out using the BLAST tool at NCBI (http://www. ncbi.nlm.nih.gov/blast). The deduced amino acid sequence was analyzed with the Predict Protein Analysis System (http://www.predictprotein.org/). Multiple sequence alignments were performed with DNAMAN software (Version 5.2.2.0, Lynnon Biosoft, USA).

\section{Semi-quantitative RT-PCR Reaction}

Tissues of stem, tendril, flowers ( $5 \mathrm{~d}$ after flowering ), leaves, and grape skin ( $50 \mathrm{~d}$ after flowering) were collected from V. pseudoreticulata clone "Baihe-35-1" and monitored for tissue-specific expression using a semi-quantitative RTPCR technique (described below). A pair of gene-specific primers (VpRBR-F 5'-CCA GGA CGT GAA GGG GAA AC-3', VpRBR-R 5'-GCA AGC CCA TAG AAA CAA CAG AG-3') were designed using Primer Premier 5.0 (PREMIER Biosoft International, Silicon Valley, USA) following the recommended guidelines for qRT-PCR primer design, and primers specific for the grapevine Actin1 gene (GenBank accession no. AY680701) were used as the internal control. The primers for Actin1 gene were 5'-GAT TCT GGT GAT GGT GTG AGT-3' and 5'-GAC AAT TTC CCG TTC AGC AGT-3'. First-strand cDNA was synthesized using One Step PrimeScript ${ }^{\mathbb{R}}$ miRNA cDNA Synthesis Kit (TaKaRa Biotechnology, Dalian, China). Semi-quantitative RT-PCR was performed at $94^{\circ} \mathrm{C}$ for $3 \mathrm{~min}$, followed by 30 cycles at $94^{\circ} \mathrm{C}$ for $30 \mathrm{~s}, 60^{\circ} \mathrm{C}$ for $30 \mathrm{~s}$ and $72^{\circ} \mathrm{C}$ for $30 \mathrm{~s}$, and a final extension at $72^{\circ} \mathrm{C}$ for $5 \mathrm{~min}$. The RT-PCR products from each tissue were subject to electrophoresis on $1.5 \%$ agarose gels. The experiments were repeated three times with similar results; a representative result is presented.

\section{Quantitative Real-Time Reaction}

The target gene products were amplified with primers VpRBR-F (forward) and VpRBR-R (reverse). Relative levels of gene expression were analyzed with the iCycler iQ5 ${ }^{\text {TM }}$ Real-Time PCR Detection System (Bio-Rad, Hercules, CA, USA) and normalized with the results for Actin1. Each $25 \mu$ l PCR reaction contained $12.5 \mu 1$ of $\mathrm{SYBR}^{\circledR}$ Premix Ex Taq TM II (2×), $1 \mu$ of PCR Forward Primer $(10 \mu \mathrm{M}), 1 \mu \mathrm{l}$ of PCR Reverse Primer( $10 \mu \mathrm{M}), 2 \mu \mathrm{l}$ of $10 \times$ diluted cDNA, and $8.5 \mu \mathrm{l}$ of $\mathrm{ddH}_{2} \mathrm{O}$. Reactions were performed by an initial 
incubation at $50^{\circ} \mathrm{C}$ for $2 \mathrm{~min}$ and at $95^{\circ} \mathrm{C}$ for $30 \mathrm{~s}$, followed by 40 cycles of $95^{\circ} \mathrm{C}$ for $5 \mathrm{~s}$, and $60^{\circ} \mathrm{C}$ for $30 \mathrm{~s}$. Output data generated by the instrument on-board software iQ5 (Bio-Rad) were transferred to Sigmaplot software (v.10.0, Systat Inc., CA, USA) for analysis. Real-time quantitative RT-PCR was performed in three replicates for each sample.

\section{Results}

Isolation and Sequence Analysis of $V p R B R$ Gene

The 3' RACE and 5'RACE products were 1,133 bp and $2,169 \mathrm{bp}$, respectively. By comparing and aligning the sequences of 5' RACE and 3' RACE, the sequence of full-length cDNA was deduced. It contained 3,030 bp with a 3,024-bp open reading frame encoding 1,007 amino acids (calculated molecular mass of $117.3 \mathrm{kDa}$ ). A retinoblastoma-associated protein domain A from amino acid residues 416 to 579, and domain B from residues 726 to 855 were present in the deduced amino acid sequence of the $V P R B R$ gene (Fig. 1).

A search of the NCBI databases with BLAST showed that the deduced amino acid sequence of $V p R B R$ shares 99$70 \%$ identity with the predicted protein from $V$. vinifera (99\%, accession no. XP_002280874.1), Ricinus communis (79\%, accession no. B9SVG9.1), Populus trichocarpa (76\%, accession no. XP_002297730.1), Cocos nucifera (70\%, CnRBR, accession no. Q8H252.1) (Fig. 1).

\section{Expression Analysis of $V p R B R$ in Grape Organs}

To analyze the expression of $V p R B R$ in different grapevine organs, the leaves, stem, tendrils, flower, and grape skin of $V$. pseudoreticulat clones "Baihe-35-1" were examined by semi-quantitative PCR. The Actin1 gene was selected as a constitutive control to normalize the samples for differences in the amount of RNA. The result suggested that $V p R B R$ was expressed in all the tissues examined from "Baihe-35-1" (Fig. 2).

Induced Expression of the RBR Gene in PM-Resistant and -Susceptible Grapevines

To investigate whether the PM-induced expression pattern varied in different grapevine genotypes, the expression of RBR in PM-resistant clones "Baihe-35-1" and "Baihe-131", and PM-susceptible clone "Hunan-1" was analyzed in leaves using a qRT-PCR method (Fig. 3). In PM-resistant clones "Baihe-35-1" and "Baihe-13-1", similar trends of the $V p R B R$ transcripts at the early times after inoculation with $E$. necator were observed. Although there was some fluctuation in transcript levels in "Baihe-13-1", both resistant clones remained at higher levels than the controls $(0 \mathrm{~h})$ throughout the duration of the experiment. In addition, the magnitude of the increase of $V p R B R$ in "Baihe-13-1" was considerably higher than in "Baihe-35-1". In contrast, the transcripts of RBR in the PM-susceptible clone "Hunan-1" were not observed to change appreciably over the time course of the experiment. It should be noted that the transcription levels from both resistant clones reached a maximum at 8 hpi, i.e., over 10-fold for "Baihe-13-1" and approximately two-fold for "Baihe-35-1".

Induction of the VpRBR in Grape Leaves by MeJA, SA, and Eth

To test the effect of MeJA, SA, and Eth on the expression of $V p R B R$, leaves of "Baihe-35-1", "Baihe-13-1", and "Hunan1 " were sprayed with $0.5 \mathrm{~g} / \mathrm{L}, 100 \mu \mathrm{M}$, and $50 \mu \mathrm{M}$, respectively. The results showed that the $V p R B R$ transcripts were expressed at different levels after exogenous application of MeJA, SA, and Eth (Fig. 4).

In general, the PM-resistant clones, "Baihe-35-1" and "Baihe-13-1", showed higher expression of VPRBR than the PM-susceptible clone "Hunan-1"after exogenous application of MeJA, SA, and Eth (Fig. 4).

In general, expression of $V P R B R$ in "Baihe-35-1" and "Baihe-13-1" was greatly enhanced after SA treatments. Levels reached a maximum at $8 \mathrm{~h}$, over 10 -fold for both clones, decreased, and then remained at higher levels than controls $(0$ h). For "Hunan-1", VpRBR expression in response to SA peaked (over 2-fold) at $12 \mathrm{hpi}$, but transcript levels were lower than in the PM-resistant clones. JA induced VPRBR in both "Baihe-35-1" and "Baihe-13-1".Transcript levels began to increase at $0.5 \mathrm{~h}$, reaching a maximum at $6 \mathrm{~h}$ ("Baihe-35-1") and $12 \mathrm{~h}$ ("Baihe-13-1"). In "Hunan1 ", $V p R B R$ expression was weakly induced by exogenous $\mathrm{JA}$ and decreased at $6 \mathrm{~h}$, followed by an increase that was significantly lower than what was observed in the PMresistant clones. Expression of $V p R B R$ in "Baihe-13-1"was sharply increased under Eth treatment, reached its highest level at $1 \mathrm{~h}$, decreased from $1 \mathrm{~h}$ to $3 \mathrm{~h}$, and ended at slightly higher than basal expression levels. A dramatic increase of $V p R B R$ in "Baihe-35-1" was observed from the time of application of exogenous Eth. It reached its highest level at $6 \mathrm{~h}$, and then decreased slightly, finally reaching a slightly higher level than "Baihe-13-1" and "Hunan-1". The expression of VPRBR in "Hunan-1" was for the most part lower than that of both PM-resistant clones (Fig. 4).

\section{Discussion}

$R B$ genes comprise small family genes that have been extensively characterized in higher eukaryotes. Functional analysis indicates that $R B$ genes act as "gatekeepers" in the 


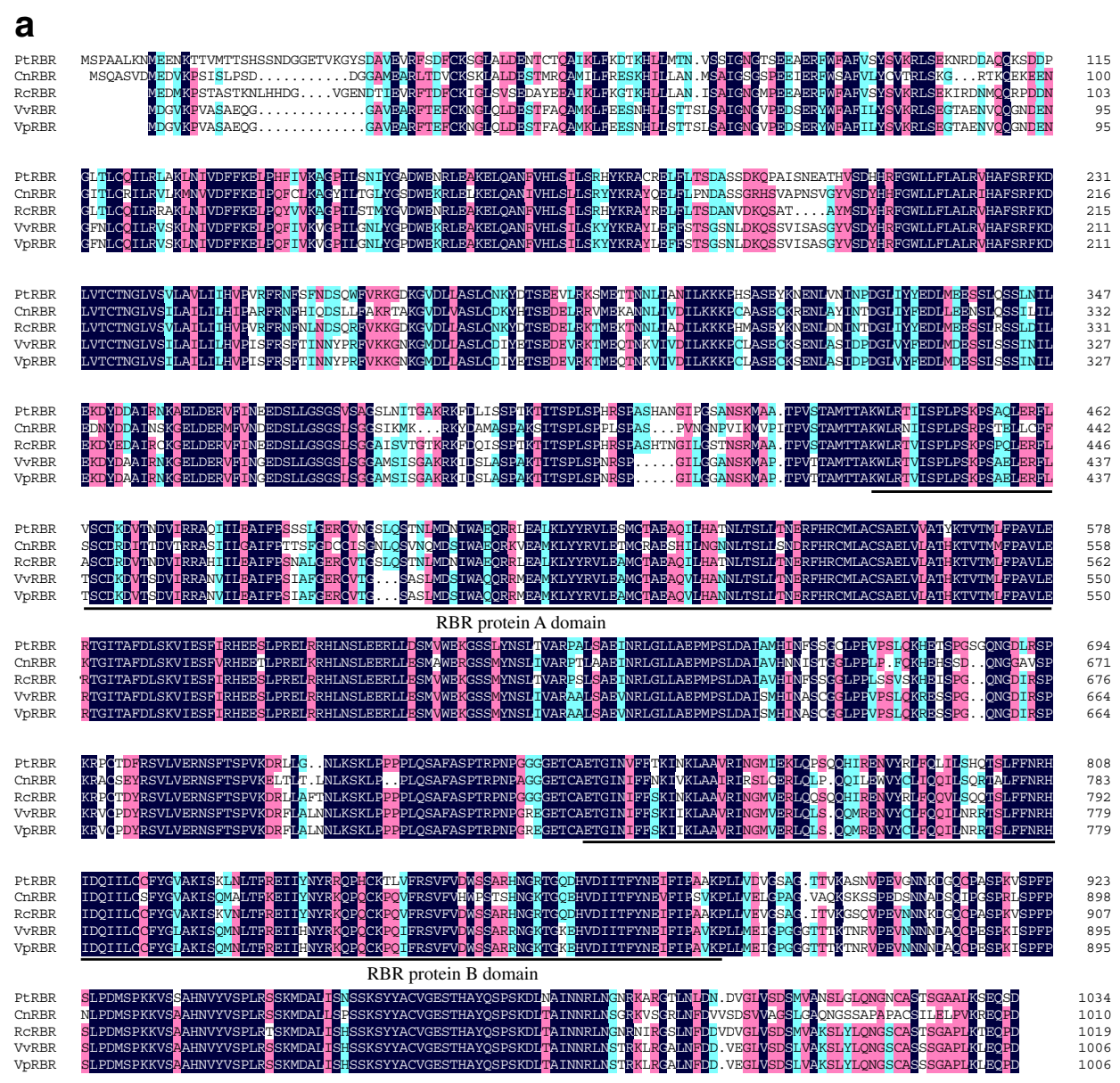

b

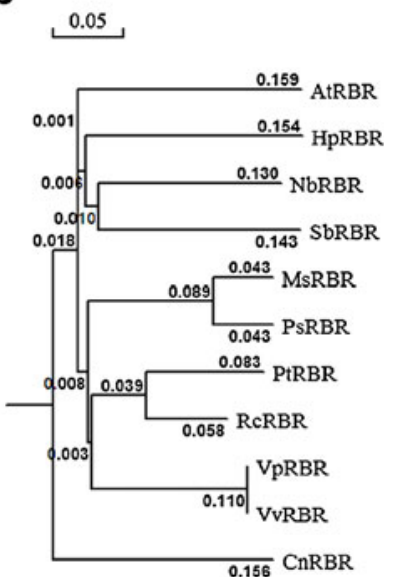

Fig. 1 a Multiple sequence alignment of $V p R B R$ with other RBR proteins in plants. The underlined amino acid residues (416 to 579 and 726 to 855 ) indicate $R B R$ protein $A$ and $B$ domains, respectively. Gaps to optimize alignments are designated by dots. Arrows indicate the relative positions of the forward and reverse primers used in the expression analyses. The consensus amino acid identity among all organisms is indicated by black color. Amino acids are numbered on the right side of the sequence. The cDNA clone has been deposited to GenBank (GenBank No. JN585760). The GenBank accession number of the $R B R$ proteins from other plants are as follows: $V$. vinifera $(V v R B R$, Acc. No. XP 002280874), R. communis (RcRBR, Acc. No. B9SVG9), P. trichocarpa (PtRBR,Acc. No. XP_002297730), C. nucifera (CnRBR, Acc. No.
Q8H252). b. The phylogenetic tree analysis with other related $V p R B R$ proteins in plants. The tree was constructed from the alignment using the DNAMAN program. The scale bar represents 0.05 substitutions per site, the numbers beside the branches represent bootstrap values. The GenBank accession number of the $R B R$ proteins are as follows: $R$. communis (RcRBR, Acc. No. B9SVG9), P. trichocarpa (PtRBR, Acc. No. XP_002297730), M. sativa (MsRBR, Acc. No. A9UL14), A. thaliana (AtRBR, Acc. No. NP_001189868), P. sativum (PsRBR, Acc. No. Q9SLZ4), V. vinifera (VvRBR, Acc. No. XP 002280874), N. benthamiana (NbRBR, Acc. No. Q66WV0), H. piloselloides (HpRBR, Acc. No. B1ABR6), S. baicalensis (SbRBR, Acc. No. Q4JF75), C. nucifera (CnRBR, Acc. No. Q8H252) 


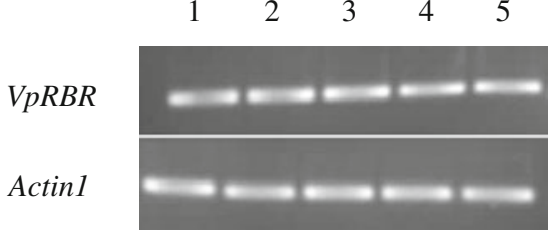

Fig. 2 Organ expression in grape leaves, stems, tendrils, flowers, and grape skin from Vitis pesudoreticulata clone "Baihe-35-1" by semiquantitative PCR. Lane 1: Leaves; Lane 2: Stems; Lane 3: Tendrils; Lane 4: Flowers; Lane 5: grape skin

cell cycle, thus preventing inappropriate cell proliferation (Sabelli and Larkins 2009). Previous studies suggested that $p R B R$ possesses a small and a large pocket region, which is necessary for interaction with proteins containing a conserved L-x-C-x-E motif. Moreover, the larger region of RBR can bind to E2F transcription factors, and is involved in the downstream gene expression and regulation of the E2F and DP family of transcription factors (Morris and Dyson 2001). It has also been shown that $p R B R$ could regulate a series of cellular processes involved in RNA production, tissue development, and RNA processing (Sabelli and Larkins 2009). A recent study indicated that the RBR gene, both in animals and plants, plays a central role in regulating, integrating, and connecting pathways that impinge on cell differentiation, development, cell death, and epigenetic mechanisms (Sabelli and Larkins 2009). Our sequence analyses indicated that the $\operatorname{VPRBR}$ from Chinese wild $V$. pseudoreticulat clone "Baihe-35-1" shares a high level of sequence homology with other plant RBR genes, and the highest homology

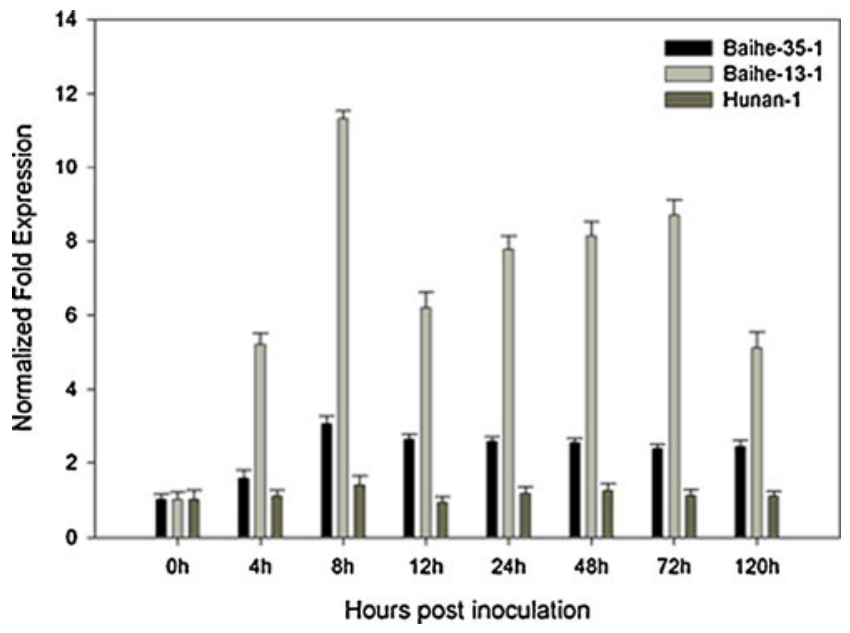

Fig. 3 Expression profiles of $V p R B R$ in three grapevine genotypes induced after E.necator by qRT-PCR. Each experiment was repeated three times, and the standard error bars are indicated. Total RNA was extracted from leaves of Vitis pesudoreticulata clone "Baihe-35-1", "Baihe-13-1", and "Hunan-1", and analyzed at 0, 4, 8, 12, 24, 48, 72 and $120 \mathrm{~h}$ after E. necator inoculation
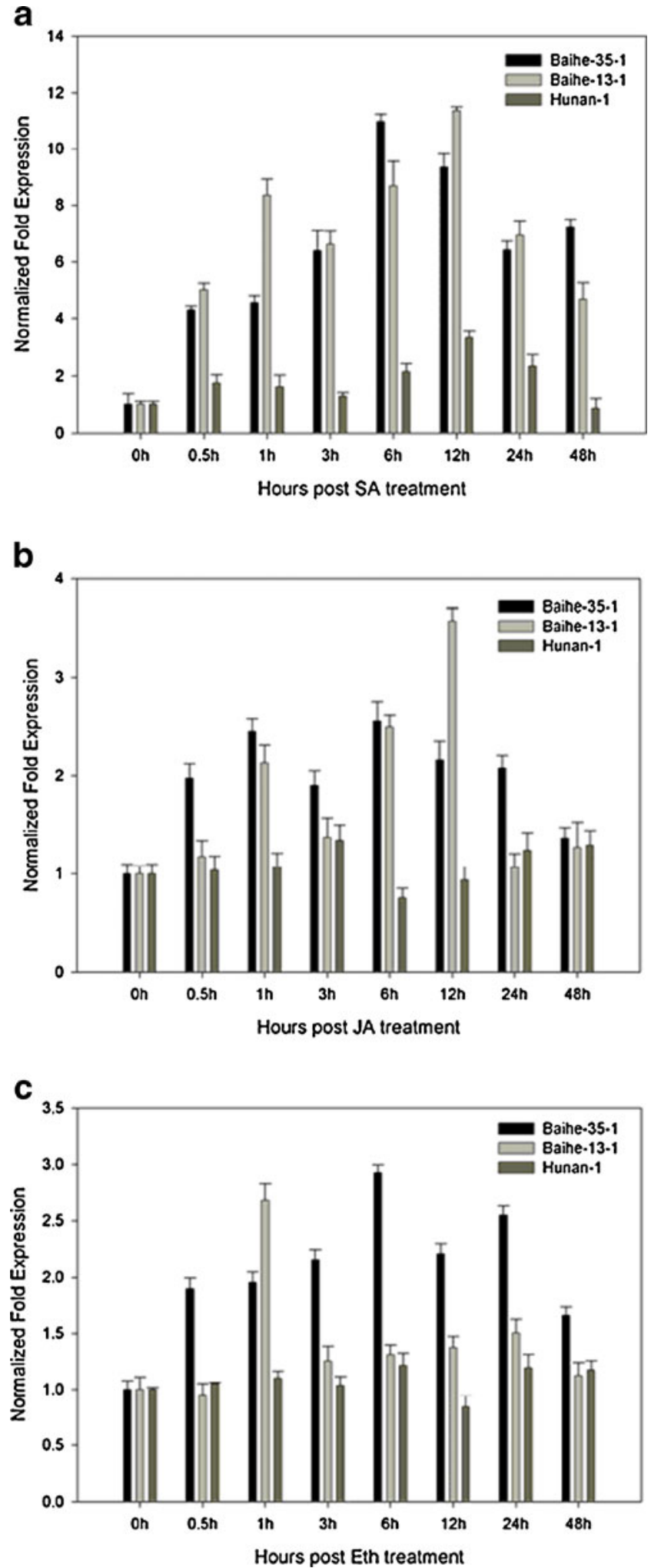

Fig. 4 qRT-PCR expression profiles of $V p R B R$ in three grapevine genotypes induced by SA, MeJA, and Eth treatments. a SA treatment. b MeJA treatment. $\mathbf{c}$ Eth treatment. Each experiment was repeated three times, and the standard error bars are indicated. Total RNA from leaves of Vitis pesudoreticulata clone "Baihe-35-1", "Baihe-13-1", and "Hunan1 " was analyzed $0,0.5,1,3,6,12,24$ and $48 \mathrm{~h}$ after the treatments with MeJA, SA and Eth 
(99\%) has been associated with two conserved domains of the known sequences.

Semi-quantitative RT-PCR analysis showed that $V p R B R$ was expressed constitutively in different organs in "Baihe35-1", a result similar to those reported in maize (Ach et al. 1997) and tobacco (Nakagami et al. 1999). Evidence also indicates that RBR plays an important role in organ development in monocot species (Lendvai et al. 1997). Based on these observations, together with our results, VPRBR may play different roles in different organs. It is worth noting that the $V p R B R$ expressed in all the tissues examined from "Baihe-35-1", which is different from maize where it had a highest expressed level occurred in the shoot apex (Ach et al. 1997). Further comparative studies are required to elucidate this difference in expression by location and tissue type.

Plants have evolved a wide range of defense mechanisms to cope with biotic and abiotic stresses (Qu et al. 2011; Yang et al. 2010). These defense mechanisms depend on numerous proteins, including many involved in regulating cellular response to stress and signaling crosstalk. Many of these proteins represent enzymes participating in the production of phytohormones (e.g., MeJA, SA, Eth), oxygen species, pathogenesis-related (PR) proteins (Huang et al. 2010), and transcription factors. The pathogen defense mechanism in plants has been reported to be associated with early and strong gene expression (Heitefuss 2001). We examined the expression pattern of RBR in "Baihe-35-1", "Baihe-13-1" and "Hunan-1" in response to E. necator and showed that $V P R B R$ displayed higher levels, earlier and stronger expression in the PM-resistant clones "Baihe-35-1" and "Bai-131 " than in the PM-susceptible clone "Hunan-1"under $E$. necator infection. Retinoblastoma-related proteins are negative cell regulators in animals and plants (Gutierrez 2005); however, recent studies on a maize member of the $R B$ gene family, RBR3, show that it has an essential and positive role in the cell cycle. Considering the different and opposing roles of $R B R$ genes (Sabelli and Larkins 2009), we hypothesize the following function for $V p R B R$ in grapevine: $E$. necator invades grapevine leaf cells followed by induction of the plant defense response that often includes a type of cell death known as the hypersensitive response (Moffett et al. 2002). As a result, upregulation of $V p R B R$ in Chinese wild $V$. pseudoreticulata clones "Baihe-35-1" and "Baihe13-1" shortens the G1-to-S phase transition that accelerates cell division leading to resistance to E. necator. A similar find was reported for the Arabidopsis RBR gene suggesting that it functions early in abiotic and biotic stress responses to adjust cell division to prevailing stress conditions (Borghi et al. 2010). The transcript levels of $V p R B R$ were highest in both PM-resistant clones, although the highly resistant "Baihe-35-1" was significantly lower than "Baihe-13-1". Because the highest levels were seen $8 \mathrm{~h}$ after inoculation, we infer that $8 \mathrm{~h}$ is an important time for grapevine development of resistance to E. necator. In "Hunan-1", only a slight increase or decrease in $V p R B R$ transcript levels could be detected during E. necator infection. Therefore, the difference between resistance and susceptibility to PM apparently does not rely on the presence or absence of $V p R B R$, but rather on the extent of expression during exposure to the pathogen. Taken together, we propose that high levels of $V p R B R$ correlate in a complex manner with the resistance response to $E$. necator in Chinese wild grape.

SA, MeJA, and Eth are involved in activation of signaling pathways in plant defense responses. Application of SA, $\mathrm{MeJA}$, and Eth can coordinately activate transcripts of different defense-related proteins ( $\mathrm{Lu}$ et al. 2006). SA is the signal molecule for the development of plant systemic resistance and plays an important role in disease resistance. In the present study, exogenous applications of SA led to greatly enhanced transcripts of RBR in both PM-resistant grapevine clones and in the PM-susceptible "Hunan-1". High SA levels are correlated with constitutively elevated expression of genes involved in defense responses (Fung et al. 2008). Furthermore, treatment of grapevines with benzothiadiazole, a SA analog, enhanced resistance to Botrytis cinerea (Iriti et al. 2004). We, therefore, infer that application of SA enhanced the resistance to PM in "Baihe-35-1" and "Baihe-13-1", and that VPRBR participates in the SA signaling-induced defense response in plants.

JA-Eth pathway controls the expression of a different set of defense markers in Arabidopsis (Thomma et al. 1998). Cooperation of JA and Eth synergistically induces defense gene responses to different pathogens (Pieterse et al. 1998). Grapevine leaves treated with MeJA and Eth, enhanced resistance to $\mathrm{PM}$ and increased the expression of $P R$ proteins (Belhadj et al. 2006). The application of exogenous MeJA to Arabidopsis plants reduced disease development from several fungi (Thomma et al. 1999). Similarly, Eth is known to enhance the resistance of plants to several fungi (Thomma et al. 1999). The expression of $V p R B R$ was rapidly induced by MeJA and Eth treatment in "Baihe-35-1" and "Baihe-13-1", although the fold-difference was less than that observed with SA treatment. The response of the resistant grapevine clones was transient with all three signaling molecules. In contrast, the levels of $V p R B R$ in response to applications of MeJA and SA were essentially constant and at lower levels in "Hunan-1". We, therefore, hypothesize that expression of $V P R B R$ plays a positive role in PM resistance in grapevine. More importantly, the higher level of VPRBR expression was observed 6 and $12 \mathrm{~h}$ after treatment with SA, MeJA and Eth in "Baihe-35-1" and "Baihe-13-1" which suggests that these time periods are important for the $V p R B R$ response to signaling-induced defense processes in plants. 


\section{Conclusion}

In summary, we have demonstrated that $V p R B R$ is induced by $E$. necator and exogenous signaling molecules in PMresistant grapevine leaves and likely plays a positive role in grape powdery mildew resistance. Further investigations of $V p R B R$ may aid us in understanding the mechanism(s) of $\mathrm{PM}$ resistance in grapevine.

Acknowledgment This study was supported by the National Science Foundation of China (No. 30871701, 31071782 and 30671446) and Program for New Century Excellent Talents in University (NCET-07-0702).

Open Access This article is distributed under the terms of the Creative Commons Attribution Noncommercial License which permits any noncommercial use, distribution, and reproduction in any medium, provided the original author(s) and source are credited.

\section{References}

Ach RA, Durfee T, Niller AB, Taranto P, Hanley-Bowdoin L, Zambryski PC, Gruissem W (1997) RBR1 and RBR2 encode maize retinoblastoma-related proteins that interact with a plant D-type cyclin and geminivirus replication protein. Mol Cell Bio 17:5077-5086

Ali K, Maltese F, Zyprian E, Rex M, Choi YH, Verpoorte R (2009) NMR metabolic fingerprinting based identification of grapevine metabolites associated with downy mildew resistance. Journal of Agri Food Chemi 57(20):9599-9606

Akkurt M, Welter L, Maul E, TÖpfer R, Zyprian E (2008) Development of SCAR markers linked to powdery mildew (Uncinula necator) resistance in grapevine (Vitis vinifera L. and Vitis $\mathrm{sp}$.). Mol Breed 19:103-111

Belhadj A, Saigne C, TelefN CS, Bouscaut J, Corio-Costet MF, Merillon JM (2006) Methyl jasmonate induces defense responses in grapevine and triggers protection against Erysiphe necator. $\mathrm{J}$ Agric Food Chem 54:9119-9125

Borghi LR, Gutzat R, Fütterer J, Laizet Y, Hennig L, WGruissem W (2010) Arabidopsis retinoblastoma-related is required for stem cell Maintenance, cell differentiation, and lateral organ production. Plant cell 22:1792-1811

Fekete C, Fung RW, Szabó Z, Qiu W, Chang L, Schachtman DP, Kovács LG (2009) Up-regulated transcripts in a compatible powdery mildew-grapevine interaction. Plant Physiol Biochem 47 (8):732-738

Fung RWM, Gonzalo M, Fekete C, Kovacs LG, He Y, Marsh E, McIntyre LM, Schachtman DP, Qiu WP (2008) Powdery mildew induces defense-oriented reprogramming of the transcriptome in a susceptible but not in a resistant grapevine. Plant Physiology 146:236-249

Grafi G, Burnett RJ, Helentjaris T, Larkins BA, DeCaprio JA, Sellers WR, Kaelin JWG (1996) A maize cDNA encoding a member of the retinoblastoma protein family: involvement in endoreduplication. Proc Natl Acad Sci 93:8962-8967

Gutierrez C (2005) Coupling cell proliferation and development in plants. Nat Cell Biol 7:535-541

Heitefuss R (2001) Defense reactions of plants to fungal pathogens: principles and perspectives, using powdery mildew on cereals as an example. Naturwissenschaften 88:273-283
Henanff GL, Farine S, Kieffer-Mazet F, Miclot AS, Heitz T, Mestre P, Bertsch C, Chong J (2011) Vitis vinifera VvNPR1.1 is the functional ortholog of AtNPRland its over expression in grapevine triggers constitutive activation of $P R$ genes and enhanced resistance to powdery mildew. Planta. doi:10.1007/s00425-011-1412-1

Huang XH, Lu XY, Zhao JT, Chen JK, Dai XM, Xiao W, Chen YP, Chen YF, Huang XL (2010) Maserk1 gene expression associated with somatic embryogenic competence and disease resistance response in banana (Musa spp.). Plant Mol Biol Rep 28:309-316

Iriti M, Rossoni M, Borgo M, Faoro F (2004) Benzothiadiazole enhances resveratrol and anthocyanin biosynthesis in grapevine, meanwhile improving resistance to Botrytis cinerea. Agric Food Chem 52:4406-4413

Kong LJ, Orozco BM, Roe JL, Nagar S, Ou S, Feiler HS, Durfee T, Miller AB, Gruissem W, Robertson D, Hanley-Bowdoin L (2000) A geminivirus replication protein interacts with the retinoblastoma protein through a novel domain to determine symptoms and tissue specificity of infection in plants. EMBO J 19:3485-3495

Li H, Xu Y, Xiao Y, Zhu Z, Xie X, Zhao H, Wang Y (2010) Expression and functional analysis of two genes encoding transcription factors, VpWRKY1 and VpWRKY2, isolated from Chinese wild Vitis pseudoreticulata. Planta 232(6):1325-1337

Lendvai A, Pettko-Szandtner A, Csordás-Tóth É, Miskolczi P, Horvath GV, Gyorgyey J, Dudits D (1997) Dicot and monocot plants differ in retinoblastoma-related protein subfamilies. J Exp Bot 58 (7): $1663-1675$

Lu ZX, Gaudet D, Puchalski B, Despins T, Frick M, Laroche A (2006) Inducers of resistance reduce common bunt infection in wheat seedlings while differentially regulating defense-gene expression. Physiol Mol Plant Pathol 67:138-148

Ma JF, Hou XL, Xiao D, Qi L, Wang F, Sun F, Wang Q (2010) Cloning and characterization of the BcTuR3 gene to resistance to turnip mosaic virus (TuMV) from non-heading Chinese cabbage. Plant Mol Biol Rep 28:588-596

Miskolczi P, Lendvai Á, Horváth GV, PettkÓ-Szandtner DD (2007) Conserved functions of retinoblastoma proteins: from purple retina to green plant cells. Plant Sci 172:671-683

Moffett P, Farnham G, Peart J, Baulcombe DC (2002) Interaction between domains of a plant NBS-LRR protein in disease resistance-related cell death. EMBO J 21:4511-4519

Morris EJ, Dyson NJ (2001) Retinoblastoma protein partners. Adv Cancer Res 82:1-54

Murphree AL, Benedict WF (1984) Retinoblastoma: clues to human oncogenesis. Science 223(4640):1028-1033

Nakagami H, Sekine M, Murakami H, Shinmyo A (1999) Tobacco retinoblastoma-related protein phosphorylated by a distinct cyclin-dependent kinase complex with $\mathrm{Cdc} 2 /$ cyclin D in vitro. Plant J 18:243-252

Peng H, Feng YM, Zhang H, Wei XK, Liang SC (2011) Molecular cloning and characterization of genes coding for glycine- and proline-rich proteins ( GPRPs) in soybean. Plant Mol Biol Rep. doi:10.1007/s11105-011-0363-9

Qu GZ, Zang LN, Lin HX, Gao CQ, Zheng TC, Li KL (2011) Cotransfer of $L E A$ and bZip genes from Tamarix confers additive salt and osmotic stress tolerance in transgenic tobacco. Plant Mol Biol Rep. doi:10.1007/s11105-011-0371-9

Pieterse CMJ, van Wees SCM, van Pelt JA, Knoester M, Laan R, Gerrits H, Weisbeek PJ, van Loon LC (1998) A novel signaling pathway controlling induced systemic resistance in Arabidopsis. Plant Cell 10:1571-1586

Ramming DW, Gabler F, Smilanick J, Cadle-Davidson M, Barba P, Mahanil S (2011) A single dominant locus, ren4, confers rapid non-race-specific resistance to grapevine powdery mildew. Phytopathol 101(4):502-508

Riaz S, Tenscher AC, Ramming DW, Walker MA (2011) Using a limited mapping strategy to identify major QTLs for 
resistance to grapevine powdery mildew (Erysiphe necator) and their use in marker-assisted breeding. Theor Appl Genet 122(6):1059-1073

Sabelli PA, Larkins BA (2009) Regulation and function of retinoblastomarelated plant genes. Plant Sci 177:540-548

Thomma BPHJ, Eggermont K, Penninckx IAMA, Mauch-Mani B, Vogelsang R, Cammue BPA, Broekaert WF (1998) Separate jasmonate-dependent and salicylate-dependent defense-response pathways in Arabidopsis are essential for resistance to distinct microbial pathogens. Proc Natl Acad Sci USA 95:15107-15111

Thomma BPHJ, Eggermont K, Tierens KFMJ, Broekaert WF (1999) Requirement of functional Ethylene Insensitive 2 gene for efficient resistance of Arabidopsis to infection by Botrytis cinerea. Plant Physiol 121:1093-1101
Wang XP, Wang Q, Wang YJ (2011) Cloning and analyzing the gene cDNA sequences of resistance to Uncinula necator from Vitis pseudoreticulata. Acta Agriculturae Boreali-occidentalis Sinica 20(9):117-122 (in Chinese)

Wang YJ, Liu Y, He P, Chen J, Lamikanra O, Lu J (1995) Evaluation of foliar resistance to Uncinula necator in Chinese wild Vitis species. Vitis 34(3):159-164

Yang B, Rahman M, Liang Y, Kav SSNNV (2010) Characterization of defense signaling pathways of Brassica napus and Brassica carinata in response to Sclerotinia sclerotiorum challenge. Plant Mol Biol Rep 28:253-263

Zhang JJ, Wang YJ, Wang XP, Yang KQ, Yang JX (2003) An improved method for rapidly extracting total RNA from Vitis. J Fruit Sci 53:771-787 (In Chinese) 